\title{
REGULASI MANDIRI TRANSPORTASI ONLINE DALAM \\ PEMBAYARAN PESANAN MAKANAN ATAS KONSUMEN YANG INGKAR JANJI
}

\author{
Erwin Asmadi \\ Fakultas Hukum Universitas Muhammadiyah Sumatera Utara \\ Jl. Kapt. Mukhtar Basri Nomor 3, Medan - Sumatera Utara \\ Email: erwinasmadi@umsu.ac.id
}

\begin{abstract}
Abstrak
Implementasi perlindungan konsumen sangat rinci sehingga diatur melalui Undang-Undang Perlindungan Konsumen. Tetapi hilangnya penyedia layanan aplikasi transportasi online kurang menjadi sorotan, apalagi pengemudi yang kehilangan karena pihak-pihak yang berafiliasi dengan aplikasi layanan tersebut. Makalah ini menyajikan kelemahan yang dialami oleh driver dan bagaimana perusahaan layanan aplikasi layanan online dapat menyelesaikan masalah ini. Terutama mengendalikan implementasi aplikasi transportasi online melalui regulasi diri yang dibuat oleh perusahaan penyedia aplikasi transportasi online (penyedia sistem elektronik). Peraturan ini tunduk pada dan tidak boleh bertentangan dengan hukum dan peraturan yang berlaku di Indonesia. Dalam praktiknya, kehilangan pengemudi seringkali tidak dipertanyakan, tetapi selama ada bukti pembelian, bantuan atau penggantian dimungkinkan sejauh mungkin oleh penyedia layanan aplikasi.
\end{abstract}

Kata Kunci: Konsumen, Kontrak Kredit, Pembayaran

\begin{abstract}
The implementation of consumer protection is so detailed that it is regulated through the Consumer Protection Act. But the loss of the online transportation application service providers is less in the spotlight, let alone driver losses as parties affiliated with the service application. This paper presents the disadvantages experienced by drivers and how online service application service companies are able to solve these problems. Especially controlling the implementation of online transportation applications through self-regulation made by online transportation application provider companies (providers of electronic systems). The regulation is subject to and may not conflict with the laws and regulations in force in Indonesia. In practice, the driver loss is often not questioned, but as long as there is proof of purchase, assistance or replacement is possible to the extent possible by the application service provider.
\end{abstract}

\section{Keywords: Consument, credit contract, payment}

\section{PENDAHULUAN}

Konsumen dan pelaku usaha sangat erat dengan sebuah perjanjian jual-beli yang menghasilkan suatu kesepakatan. Secara harfiah 'konsumen' diartikan sebagai orang atau perusahaan yang membeli barang tertentu atau menggunakan jasa tertentu, atau sesuatu atau seseorang yang menggunakan suatu persediaan atau sejumlah barang (Erwin Asmadi, 2018: 97). Dalam jual-beli antara pelaku usaha dan konsumen terdapat pelbagai bentuk perlindungan. Perlindungan konsumen adalah istilah yang dipakai untuk menggambarkan perlindungan hukum yang diberikan kepada konsumen dalam usahanya untuk memenuhi kebutuhannya dari hal-hal yang merugikan konsumen itu sendiri (Zulham, 2013, h. 21).

Dewasa ini, semakin canggih teknologi yang mempermudah transaksi jual-beli antara konsumen dan pelaku usaha hanya dengan mudah dan praktis, semua orang dapat menjual 
Jurnal Ilmu Hukum

FAKULTAS HUKUM UMSU
Regulasi Mandiri Trnsportasi...(Erwin Asmadi)

Volume 4 Nomor 1, Januari-Juni 2019, 103-118 DOI: https://doi.org/10.30596/dll.v4i1.3164

produknya dan/atau membeli kebutuhannya hanya dengan ujung jari saja yaitu melalui internet atau yang lebih dikenal jual beli secara online melalui sistem e-commerce dan kita harus pula terhubung melalui Internet Service Protocol (ISP).Perspektif yang muncul di tengah-tengah masyarakat, hanya konsumenyang mendapatkan perlindungan hukum. Namun faktanya, antara transaksi perdagangan elektronik terdapat pula aspek hukum yang melindungi hak-hak pelaku usaha ketika ada konsumen ingkar janji.

Pasal 6 huruf a Undang-undang Nomor 8 Tahun 1999 tentang Perlindungan Konsumen (UUPK) menentukan bahwa hak pelaku usaha adalah hak untuk menerima pembayaran yang sesuai dengan kesepakatan mengenai kondisi dan nilai tukar barang dan/atau jasa yang diperdagangkan (Abdul Halim Barkatullah, 2010, h. 39-40). Contoh pelaku usaha yang dirugikan oleh konsumen yaitu berkaitan dengan penggunaan aplikasi go-jek online yang mempermudah konsumen dalam memenuhi kebutuhannya, ternyata juga memiliki dampak kerugian bagi driver go-jek online khususnya pada konten go-food.

Adakalanya konsumen melakukan orderan melalui pemesanan makanan yang pembeliannya didahulukan oleh driver. Makanan yang dipesan konsumen dibeli dengan menggunakan uang driver. Kemudian diantar ke tempat yang dituju.Ketika driver sudah sampai pada tempat yang ditentukan, ternyata dengan berbagai alasan konsumen tidak mau bayar atau pemesanannya dicancel dengan berbagai alasan. Kondisi itu sangat merugikan driver, selain uangnya tidak kembali, ianya juga akan memperoleh rating/peringkat yang tidak baik.

Berdasarkan kondisi tersebut, perlu dikemukakan regulasipelaku usaha atas driveryang tidak menerima haknya setelah melaksanakan kewajibannya. Sesuai prestasi yang telah dibuatnya dengan konsumen, transaksi pelaku usaha dan konsumen cukup dimudahkan jika dilakukan secara online tetapi tetap ada saja celah yang mengakibatkan munculnya dampakdampak dari transaksi secara online itu.

Pertanggungjawaban konsumen yang ingkar janji dalam pemesanan makanan yang uangnya didahulukan oleh driver online harus diperjelas agar memiliki kepastian hukum. Sehingga mindset (pola pikir) masyarakat akan terbentuk jika pertanggungjawaban itu dapat diketahui khalayak.Harapannya agar tidak ada lagi hak-hak driver yang dilanggar seperti yang dialami. Selain konsumen, pelaku usaha juga dijamin hak-haknya oleh hukum positif Indonesia.

Tetapi mengenai keadaan itu, banyak masyarakat yang belum mengetahui bahwa menerima pembayaran merupakan sesuatu hak yang harus diterima pelaku usaha setelah melaksanakan kewajibannya dan hak itu disebut sebagai hak mutlak, yakni setiap kekuasaan mutlak yang oleh hukum diberikan kepada subyek hukum untuk berbuat sesuatu atau bertindak akan memperhatikan kepentingannya (R. Soeroso, 2006, h. 278).

\section{METODE PENELITIAN}

Jenis penelitian hukum dapat dibedakan menjadi penelitian hukum normatif dan penelitian hukum empiris/sosiologis. Penelitian hukum normatif merupakan penelitian yang 
Jurnal Ilmu Hukum

FAKULTAS HUKUM UMSU
Regulasi Mandiri Trnsportasi...(Erwin Asmadi)

Volume 4 Nomor 1, Januari-Juni 2019, 103-118 DOI: https://doi.org/10.30596/dll.v4i1.3164

datanya bersumber pada data sekunder dan berhubung data penelitian ini adalah data sekunder, maka termasuk dalam jenis penelitian hukum normatif. Sifat penelitian ini adalah deskriptif, yang bertujuan untuk memberikan gambaran tentang gejala-gejala sosial yang terkait dengan masalah kebijakan go-jek dalam meregulasiingkar janjinya konsumen dari pembayaran atas makanan yang didahulukan driver. Sumber data penelitian berupa bahan hukum primer, bahan hukum sekunder dan bahan hukum tersier. Metode pengumpulan data dilakukan menggunakan teknik studi dokumen, yang dianalisis dengan menggunakan teknik analisis kualitatif.

\section{PEMBAHASAN}

\section{Regulasi Electronic Commerce Dalam Persfektif Hukum Positif Indonesia}

Transaksi jual beli secara elektronik (e-commerce), sama halnya dengan transaksi jual beli biasa yang dilakukan di dunia nyata, dilakukan oleh para pihak yang terkait, walaupun dalam jual beli secara elektronik ini pihak-pihaknya tidak bertemu secara langsung satu sama lain, tetapi berhubungan melalui internet. E-commerce berfokus pada penggunaan ICT untuk mengaktifkan kegiatan eksternal dan hubungan bisnis dengan individu, kelompok dan usaha lainnya.Hakikatnya, e-commerce adalah proses pembelian, mentransfer, atau bertukar produk, jasa, dan/atau informasi melalui jaringan komputer, termasuk internet (Edmon Makarim, 2003, h. 65).

Menurut Edmon Makarim (2003, h.72), jenis-jenis e-commerce antara lain:

a. Business to business, yakni bisnis komunikasi antar pelaku bisnis atau transaksi secara elektronik antar perusahaan yang dilakukan secara rutin dan dalam kapasitas produk yang besar. Contohnya http://www.alibaba.com.

b. Costumers to costumers, yakni sistem komunikasi dan transaksi bisnis antar konsumen untuk memenuhi kebutuhan tertentu pada saat tertentu. Contohnya www.kaskus.co.id (Ridho Satria, 2017).

c. Costumers to bussines, yakni individu yang menjual jasa kepada organisasi dan individu yang mencari penjual dan melakukan transaksi. Contohnya www.priceline.com.

d. Customer to government, yakni transaksi jual beli yang dilakukan antara individu dengan pemerintah, contohnya dalam pembayaran pajak.

Indonesia menganut asas legalitas sehingga harus dihindarkkan adanya situasi kekosongan hukum dan segala sesuatunya harus dilindungi oleh hukum, karena tujuan hukum adalah memberikan kepastian, kemanfaatan, keadilan serta perlindungan (pengayoman) kepada masyarakat (Edmon Makarim, 2003, h. 242). Walaupun belum diberlakukan Undangundang Nomor11 Tahun 2008 tentang Informasi dan Transaksi Elektronik sebagaimana yang telah diubah dengan Undang-undang Nomor19 Tahun 2016 (UU ITE), kegiatan-kegiatan yang berhubungan dengan e-commercetelah diatur dalam berbagai peraturan perundangundangan seperti Undang-undang Nomor 12 Tahun 2002 tentang Hak Cipta, Undang-undang Nomor 14 Tahun 2001 tentang Paten, Undang-undang Nomor 15 Tahun 2001 tentang Merek, Undang-undang Nomor 36 Tahun 1999 tentang Telekomunikasi, UUPKdan lain-lain. 
Jurnal Ilmu Hukum

FAKULTAS HUKUM UMSU
Regulasi Mandiri Trnsportasi...(Erwin Asmadi)

Volume 4 Nomor 1, Januari-Juni 2019, 103-118 DOI: https://doi.org/10.30596/dll.v4i1.3164

Misalnya saja dalam Pasal 1333 KUHPerdata, barang yang menjadi objek suatu perjanjian ini harus tertentu, setidak-tidaknya ditentukan jenisnya,asalkan saja kemudian dapat ditentukan atau diperhitungkan. Menurut Riduan Syahrani (2004, h. 209-210), maka suatu hal tertentu dalam perjanjian adalah barang yang menjadi objek suatu perjanjian.

Penjelasan umum UUPK mengemukakan faktor utama yang menjadi penyebab eksploitasi terhadap konsumen sering terjadi karena masih rendahnya kesadaran konsumen akan haknya yang berbelanja secara online maupun secara langsung. Tentunya, hal ini terkait erat dengan rendahnya pendidikan konsumen,oleh karena itu keberadaan UUPK adalah sebagai landasan hukum yang kuat bagi upaya pemberdayaan konsumen.

Kegiatan jual beli yang dilakukan melalui komputer ataupun handphone dapat dikategorikan sebagai suatu transaksi elektronik. Pasal 9 UU ITE mewajibkan pelaku usaha untuk memberikan informasi yang lengkap dan benar tentang syarat kontrak, produsen, dan produk yang ditawarkan.Hakikatperselisihan maupun penipuan secara online tidak jauh berbeda dengan penipuan secara konvensional yang membedakannya hanyalah sarana perbuatannya, dalam penipuan secara online, penipuan tersebut menggunakan sarana elektronik. Untuk itu, penipuan secara online dapat pula digunakan Pasal 378 KUHP untuk menjerat pelakunya. Sedangkan dalam UU ITE, dapat dilihat dalamPasal 28 ayat 1 yang menyatakan: "Setiap Orang dengan sengaja dan tanpa hak menyebarkan berita bohong dan menyesatkan yang mengakibatkan kerugian konsumen dalam Transaksi Elektronik."

Saat ini, belum ada mekanisme pengaduan yang mudah bagi pihak yang menderita kerugian. Mekanisme yang ada saat ini hanyalah sistem pengaduan sesuai dengan Undangundang Nomor 8 Tahun 1981 tentang Hukum Acara Pidana (KUHAP). Mekanisme ini dinilai kurang cocok jika diterapkan pada sistem pengaduan dalam perdagangan online. Karena adanya paradigma bahwa biaya untuk pelaporan tersebut lebih besar daripada kerugiannya itu sendiri.

Dibutuhkan suatu sistem pengaduan yang cepat, mudah dan terutama harus secara online juga. Ada baiknya aparat penegak hukum juga mengeluarkan daftar hitam (blacklist) bagi pengguna perdagangan secara online ini yang telah terbukti merugikan pihak lain. Dengan cara ini, maka para pelanggan akan semakin merasa aman dan tidak menimbulkan kekhawatiran akan adanya suatu penipuan dalam perdagangan online atau e-commerce (Defry Prastya, 2017).

Selain UU ITE, berkaitan dengan cacat kehendak dalam pembentukan kata sepakat diatur dalam Kitab Undang-Undang Hukum Perdata (KUHPerdata). Adapun macam-macam cacat kehendak yaitu: (Yahman. 2015, h. 64)

a. Kekhilafan (dwaling), kekhilafan ini tidak mengakibatkan batalnya suatu persetujuan selainnya apabila kekhilafan itu terjadi mengenai hakikat barang yang menjadi pokok persetujuan sebagaimana disebut Pasal 1322 KUHPerdata (R. Subekti, 2004, h. 339).

b. Paksaan (dwang) sebagaimana diatur Pasal1323 KUHPerdata. Paksaan yang dilakukan terhadap orang yang membuat suatu perjanjian merupakan alasan untuk batalnya perjanjian, juga apabila paksaan itu dilakukan oleh seorang pihak ketiga, 
untuk kepentingan siapa perjanjian tersebut tidak telah dibuat (R. Subekti, 2004, h.340).

c. Penipuan (bedrog) sebagaimana diatur Pasal1328 KUHPerdata. Penipuan merupakan suatu alasan untuk pembatalan perjanjian, apabila tipu muslihat, yang dipakai oleh salah satu pihak adalah sedemikian rupa sehingga terang dan nyata bahwa pihak yang lain tidak telah membuat perikatan itu jika tidak dilakukan tipu muslihat tersebut. Penipuan tidak dipersangkakan, tetapi harus dibuktikan (R. Subekti, 2004, h. 340).

Kekosongan hukum yang mengatur tentang E-commerce harus dihindarkan karena akan menimbulkan masalah-masalah seperti (Defry Prastya, 2017): (1) Otentikasi subyek hukum yang membuat transaksi melalui internet; (2) Saat perjanjian berlaku dan memiliki kekuatan mengikat secara hukum; (3) Obyek transaksi yang diperjualbelikan; (4) Mekanisme peralihan hak; (5) Hubungan hukum dan pertanggungjawaban para pihak yang terlibat dalamtransaksi baik penjual, pembeli, maupun para pendukung seperti perbankan,Internet Service Provider (ISP)dan lain-lain; (6) Legalitas dokumen catatan elektronik serta tanda tangan digital sebagai alatbukti; (7) Mekanisme penyelesaian sengketa; (8) Pilihan hukum dan forum peradilan yang berwenang dalam penyelesaiansengketa; (9) Masalah perlindungan konsumen, HAKI dan lain-lain.

Kehadiran UU ITE memberikan dua hal penting yakni, pertama pengakuan transaksi elektronik dan dokumen elektronik dalam kerangka hukum perikatan dan hukum pembuktian, sehingga kepastian hukum transaksi elektronik dapat terjamin dan yang kedua diklasifikasikannya tindakan-tindakan yang termasuk kualifikasi pelanggaran hukum terkait penyalahgunaan TI (Teknologi Informasi) disertai dengan sanksi pidananya. Dengan adanya pengakuan terhadap transaksi elektronik dan dokumen elektronik maka setidaknya kegiatan ecommerce mempunyai basis legalnya.Walaupun beberapa permasalahan yang ada sudah dapat diselesaikan dengan munculnya UU ITE ini, namun mengenai masalah perlindungan konsumen dalam e-commerce masih perlu untuk dikaji lebih dalam, apakah UU ITE sudah mampu memberikan perlindungan hukum bagi konsumen (Defry Prastya, 2017).

\section{Regulasi Mandiri Dan Praktik Pemesanan Makanan Melalui Layanan Aplikasi Transportasi Online}

Regulasi mandiri adalah ketentuan atau norma yang dibuat secara mandiri oleh penyelenggara sistem elektronik dalam menyelenggarakan sistem elektroniknya. Ketentuan untuk menggunakan aplikasi dalam pemesanan makanan melalui go-jek online (Gojek, dalam www.go-jek.com) dapat dijabarkan sebagai berikut:

a. Konsumen menyatakan dan menjamin bahwa Konsumen adalah individu yang secara hukum berhak untuk mengadakan perjanjian yang mengikat berdasarkan hukum Negara Republik Indonesia, khususnya Ketentuan Penggunaan, untuk menggunakan Aplikasi dan bahwa Konsumen telah berusia minimal 21 tahun atau sudah menikah dan tidak berada di bawah perwalian. Jika tidak, Pihak go-jek atau Penyedia Layanan terkait, berhak berdasarkan hukum untuk membatalkan perjanjian yang dibuat dengan Konsumen. Konsumen selanjutnya menyatakan dan 
menjamin bahwa Konsumen memiliki hak, wewenang dan kapasitas untuk menggunakan Layanan dan mematuhi Ketentuan Penggunaan. Jika Konsumen mendaftarkan atas nama suatu badan hukum, Konsumen juga menyatakan dan menjamin bahwa Konsumen berwenang untuk mengadakan, dan mengikatkan diri entitas tersebut pada Ketentuan Penggunaan ini dan mendaftarkan untuk Layanan dan Aplikasi.

b. Pihak go-jek mengumpulkan dan memproses informasi pribadi Konsumen, seperti nama, alamat surat elektronik (e-mail), dan nomor telepon seluler Konsumen ketika Konsumen mendaftar. Konsumen harus memberikan informasi yang akurat dan lengkap, memperbaharui informasi dan setuju untuk memberikan kepada Pihak gojek bukti identitas apapun yang secara wajar dapat Pihak go-jek mintakan. Jika informasi pribadi yang Konsumen berikan kepada Pihak go-jek ada yang berubah, misalnya, jika Konsumen mengubah alamat surel, nomor telepon, atau jika Konsumen ingin membatalkan akun Konsumen, mohon perbaharui rincian informasi Konsumen dengan mengirimkan permintaan Konsumen kepada Pihak gojek. Pihak go-jek akan, sepanjang yang dapat Pihak go-jek lakukan, memberlakukan perubahan yang diminta tersebut dalam waktu lima belas (15) hari kerja sejak diterimanya pemberitahuan perubahan.

c. Konsumen hanya dapat menggunakan Aplikasi ketika Konsumen telah mendaftar pada Aplikasi tersebut. Setelah Konsumen berhasil mendaftarkan diri, Aplikasi akan memberikan Konsumen suatu akun pribadi yang dapat diakses dengan kata sandi yang Konsumen pilih.

d. Hanya Konsumen yang dapat menggunakan akun Konsumen sendiri dan Konsumen berjanji untuk tidak memberikan wewenang kepada orang lain untuk menggunakan identitas Konsumen atau menggunakan akun Konsumen. Konsumen tidak dapat menyerahkan atau mengalihkan akun Konsumen kepada pihak lain. Konsumen harus menjaga keamanan dan kerahasiaan kata sandi akun Konsumen dan setiap identifikasi yang Pihak go-jek berikan kepada Konsumen. Dalam hal terjadi pengungkapan atas kata sandi Konsumen, dengan cara apapun, yang mengakibatkan setiap penggunaan yang tidak sah atau tanpa kewenangan atas akun atau identitas Konsumen, pesanan yang diterima dari penggunaan yang tidak sah atau tanpa kewenangan tersebut masih akan dianggap sebagai pesanan yang sah, kecuali Konsumen memberitahu Pihak go-jek tentang mengenai hal tersebut sebelum Penyedia Layanan memberikan Layanan yang diminta.

e. Konsumen hanya dapat memiliki satu akun go-jek.

f. Informasi yang diberikan oleh Aplikasi tidak dapat diartikan sebagai suatu saran atau penawaran, keputusan untuk menggunakan Penyedia Layanan sepenuhnya berada di tangan Konsumen. Konsumen bebas untuk memilih untuk menggunakan penyedia layanan lainnya.

g. Konsumen berjanji bahwa Konsumen akan menggunakan Aplikasi hanya untuk tujuan yang dimaksud untuk mendapatkan Layanan. Konsumen tidak diperbolehkan untuk menyalahgunakan atau menggunakan Aplikasi untuk tujuan penipuan atau menyebabkan ketidaknyamanan kepada orang lain atau melakukan pemesanan makanan palsu.

h. Jika Konsumen juga adalah seorang Penyedia Layanan, Konsumen tidak dapat menggunakan akun konsumen Konsumen sendiri (atau akun milik konsumen orang 
lain) untuk melakukan pemesanan makanan yang akan Konsumen terima sendiri sebagai seorang pengemudi.

i. Konsumen tidak diperkenankan untuk membahayakan, mengubah atau memodifikasi Aplikasi dan/atau Situs web atau mencoba untuk membahayakan, mengubah atau memodifikasi Aplikasi dan/atau Situs web dengan cara apapun. Pihak go-jek tidak bertanggung jawab jika Konsumen tidak memiliki perangkat yang sesuai atau jika Konsumen telah mengunduh versi Aplikasi yang salah untuk perangkat Konsumen. Pihak go-jek berhak untuk melarang Konsumen untuk menggunakan Aplikasi lebih lanjut jika Konsumen menggunakan Aplikasi dengan perangkat yang tidak kompatibel/cocok atau tidak sah atau untuk tujuan lain selain daripada tujuan yang dimaksud untuk penggunaan Aplikasi ini. Konsumen berjanji bahwa Konsumen hanya akan menggunakan suatu jalur akses yang diperbolehkan untuk Konsumen gunakan.

j. Konsumen akan menjaga kerahasiaan dan tidak akan menyalahgunakan informasi yang Konsumen terima dari penggunaan Aplikasi tersebut. Konsumen akan memperlakukan Penyedia Layanan dengan hormat dan tidak akan terlibat dalam perilaku atau tindakan yang tidak sah, mengancam atau melecehkan ketika menggunakan layanan mereka.

k. Konsumen memahami dan setuju bahwa penggunaan Aplikasi oleh Konsumen akan tunduk pula pada Kebijakan Privasi Pihak go-jek sebagaimana dapat diubah dari waktu ke waktu. Dengan menggunakan Aplikasi, Konsumen juga memberikan persetujuan sebagaimana dipersyaratkan berdasarkan Kebijakan Privasi Pihak gojek.

1. Dengan memberikan informasi kepada Pihak go-jek, Konsumen menyatakan bahwa Konsumen berhak untuk memberikan kepada Pihak go-jek informasi yang akan Pihak go-jek gunakan dan berikan kepada Penyedia Layanan.

m. Aplikasi tidak boleh dipergunakan untuk mencari Layanan untuk:

1) Mengangkut dan/atau memperoleh dan/atau membeli barang yang dilarang oleh pejabat yang berwenang atau barang yang memerlukan lisensi atau izin tertentu dari pejabat yang berwenang untuk dikirimkan;

2) Mengangkut barang dari dan ke penjara;

3) Membeli dan/atau mengangkut binatang peliharaan atau binatang lain;

4) Mengangkut barang-barang dengan dimensi lebih dari $70 \mathrm{~cm}$ (panjang), $50 \mathrm{~cm}$ (lebar), $50 \mathrm{~cm}$ (tinggi) atau barang-barang yang beratnya lebih dari $20 \mathrm{~kg}$;

5) Membeli dan/atau mengangkut barang-barang ilegal atau berbahaya atau barang-barang curian, termasuk namun tidak terbatas pada barang-barang yang mengandung bahan berbahaya atau beracun, obat-obatan atau material terlarang/ilegal; dan

6) Membeli dan/atau mengangkut atau mengirimkan barang-barang berharga atau barang yang bernilai lebih dari Rp10.000.000,-

n. Konsumen harus memberikan kepada Pihak go-jek informasi yang akurat dan lengkap mengenai jenis, ukuran, spesifikasi dan/atau setiap karakteristik khusus dari makanan atau barang yang akan dikirimkan dengan layanan Kurir Instan atau dibeli dengan layanan Pengiriman Makanan atau layanan Pembelanjaan Pribadi.

o. Konsumen harus mengemas dengan benar barang-barang yang rapuh, seperti gelas, keramik, kue atau makanan, untuk pengiriman. Pihak go-jek maupun Penyedia 
Layanan tidak akan bertanggung jawab atas segala kerusakan, perubahan bentuk, pembengkokan, kadaluwarsa, pembusukan, bau, tumpahan atau ketidaklengkapan lain dari produk selama pengiriman yang disebabkan oleh kemasan atau pembungkusan yang kurang baik/sesuai.

p. Penyedia Layanan dapat meminta Konsumen untuk membuka dan menunjukkan bagian dalam suatu paket untuk memastikan bahwa isinya adalah seperti yang Konsumen nyatakan.

q. Penyedia Layanan berhak untuk menolak pesanan Konsumen jika menurut penilaian pribadi Penyedia Layanan, ia mungkin tidak dapat melakukan pengiriman barang.

r. Konsumen menyatakan bahwa Konsumen telah, adalah, atau akan menjadi pemilik yang sah atas barang yang akan dikirimkan. Barang yang dikirim bukan barang curian atau diperoleh secara tidak sah dan Konsumen setuju untuk menjaga, mengganti kerugian dan membebaskan Pihak go-jek dan Pihak go-jek tidak bertanggung jawab atas barang yang dikirimkan oleh Penyedia Layanan yang mungkin melanggar peraturan perundang-undangan yang berlaku.

s. Pihak go-jek dan/atau Penyedia Layanan yang terkait berhak menolak untuk menerima pesanan Konsumen jika Pihak go-jek memiliki alasan yang wajar untuk mencurigai bahwa Konsumen telah, atau dengan menerima pesanan dari Konsumen, Konsumen akan melanggar Ketentuan Penggunaan ini atau hukum dan peraturan perundang-undangan yang berlaku.

t. Pihak go-jek dapat, berdasarkan kebijakan Pihak go-jek, memberikan promosipromosi yang dapat ditukar untuk manfaat terkait dengan penggunaan Aplikasi. Konsumen setuju bahwa Konsumen hanya akan menggunakan promosi tersebut sebagaimana promosi tersebut dimaksudkan dan tidak akan menyalahgunakan, menggKonsumenkan, menjual atau mengalihkan promosi tersebut dengan cara apapun. Konsumen juga memahami bahwa promosi tidak dapat ditukarkan dengan uang tunai dan dapat berakhir pada tanggal tertentu, bahkan sebelum Konsumen menggunakannya.

u. Untuk ketentuan Layanan Pembelanjaan Pribadi, Konsumen menyatakan bahwa barang yang akan dibeli dan dkirimkan oleh Penyedia Layanan adalah barang yang sah dan tidak melanggar hukum dan perundang-undangan yang berlaku dengan cara apapun. Konsumen setuju untuk menjaga, mengganti kerugian dan membebaskan Pihak go-jek dan Pihak go-jek tidak bertanggung jawab atas barang yang dibeli oleh Penyedia Layanan atas nama Konsumen dan diberikan kepada Konsumen yang mungkin dapat melanggar hukum dan peraturan perundang-undangan yang berlaku.

v. Konsumen mengakui dan setuju untuk memberikan kepada Penyedia Layanan kuasa dan wewenang untuk mengambil barang-barang atau makanan, melakukan suatu pembelian atas nama Konsumen untuk setiap pemesanan makanan di layanan Kurir Instan, Pengiriman Makanan, atau Pembelanjaan Pribadi.

w. Konsumen hanya dapat melakukan pemesanan makanan atas makanan yang tersedia di menu makanan restoran-restoran yang ada di layanan Pengiriman Makanan.

x. Pihak go-jek tidak menjamin ketersediaan barang pesanan di toko/restoran dan pengiriman barang-barang yang rapuh/mudah rusak seperti kue dan es krim. 
y. Pihak go-jek tidak bertanggung jawab atas kualitas makanan dan/atau barang yang disediakan oleh restoran-restoran dan/atau toko dalam layanan Pengiriman Makanan dan Pembelanjaan Pribadi.

z. Konsumen mengakui dan memahami bahwa harga makanan atau barang yang ditampilkan di layanan Pengiriman Makanan atau Pembelanjaan Pribadi adalah merupakan perkiraan dan dapat berubah dari waktu ke waktu.

aa. Konsumen setuju dan mengakui bahwa Konsumen akan membayar sesuai dengan tKonsumen terima yang diterbitkan oleh restoran atau toko yang diserahkan oleh Penyedia Layanan kepada Konsumen dalam menggunakan layanan Pengiriman Makanan dan Pembelanjaan Pribadi.

bb. Pihak go-jek atau Penyedia Layanan tidak menjamin ketersediaan makanan atau barang di restoran atau toko.

cc. Penyedia Layanan hanya akan mengirimkan minuman beralkohol untuk pelanggan yang berusia di atas 21 tahun. Konsumen setuju untuk menunjukkan kartu identitas (KTP) Konsumen untuk diperiksa oleh Penyedia Layanan pada saat pengiriman.

dd. Konsumen memahami dan mengakui bahwa dengan memilih ya pada halaman popup pemeriksaan usia saat memasuki toko minuman beralkohol atau menambahkan minuman beralkohol ke troli, Konsumen memastikan bahwa Konsumen telah melebihi batas usia yang sah untuk mengkonsumsi minuman beralkohol.

ee. Semua bir (Bintang dan Heineken) di toko bir Bintang (Bintang Store) akan dikirimkan dari toko terdekat, tidak langsung dari toko bir Bintang.

ff. Sehubungan dengan Layanan Transportasi, Konsumen berjanji bahwa Konsumen akan mengenakan helm yang disediakan oleh Penyedia Layanan Konsumen selama perjalanan. Konsumen juga berjanji bahwa untuk setiap Layanan Transportasi, hanya akan ada satu penumpang dari Penyedia Layanan. Penyedia Layanan berhak untuk menolak atau membatalkan pesanan Layanan Transportasi jika ia mengetahui bahwa jumlah penumpangnya akan lebih dari satu orang.

gg. Mohon menginformasikan kepada Pihak go-jek jika Konsumen tidak lagi memiliki kontrol atas akun Konsumen, sebagai contoh akun Konsumen dengan cara bagaimanapun diretas (hack) atau telepon Konsumen dicuri, sehingga Pihak go-jek dapat membatalkan akun Konsumen dengan sebagaimana mestinya. Mohon diperhatikan bahwa Konsumen bertanggung jawab atas penggunaan akun Konsumen dan Konsumen mungkin dapat dimintakan tanggung jawabnya meskipun jika akun Konsumen tersebut disalahgunakan oleh orang lain.

Di dalam praktik dapat dijabarkan alur pemesanan makanan melalui transportasi online dapat dipersingkat sebagai berikut:

a. Setelah ada pemberitahuan di handphone driver bahwa ada konsumen (pelanggan transportasi online) yang memesan makanan melalui aplikasi.

b. Selanjutnya, driver terhubung langsung melalui telepon dengan konsumen dan menanyakan mau pesan makanan apa. Pertanyaanya biasanya detail, contohnya, kalau mau beli ayam, ayamnya bagian paha atau dada.

c. Driver kemudian membeli makanan ke tempat yang diinginkan konsumen, kemudian mengantri dan juga membeli makanan dengan uang yang didahulukan pembayarannya menggunakan uang driver. 
Jurnal Ilmu Hukum

FAKULTAS HUKUM UMSU
Regulasi Mandiri Trnsportasi...(Erwin Asmadi)

Volume 4 Nomor 1, Januari-Juni 2019, 103-118 DOI: https://doi.org/10.30596/dll.v4i1.3164

d. Setelah itu, driver mengantar ke tempat tujuan.

Kerap terjadi, saat driver telah membeli makanan dan ingin mengantarnya ke tempat tujuan namun seketika handphone konsumen tidak dapat dihubungi, hanya upaya-upaya ringan yang dapat dilakukan, seperti melacak apakah nomor tersebut memiliki whatsapp atau line tetapi ketika tidak ada informasi petunjuk, maka disitu driver akan rugi.

Kekurang maksimalan sistem dalam melacak pemesan makanan yang fiktif membuat driver mengalami kerugian.Modus yang dilakukan konsumen untuk mengelabui pelaku usaha nampaknya sering berhasil sehingga konsumen (yang memiliki usaha makanan) memanfaatkan driver go-jek online untuk meningkatkan pendapatannya. Yang sangat menyayat hati, driver korban ingkar janji konsumen itu mengatakan kerugian yang dialaminya sama dengan pendapatannya menarik ojek seharian, sehingga tidak dapat memenuhi kebutuhannya dan/atau anak dan istrinya. Kerugian yang dialami oleh driver cukup bervariasi mulai dari Rp.50.000 sampai dengan Rp. 350.000 sehingga kerugian itu cukup terasa bagi driver yang ditipu karena tidak menerima pembayaran sebagaimana mestinya dari konsumen yang melakukan pemesanan makanan kemudian tidak jelas itu.

Selain pengaturan pemesanan makanan, akan dibahas lebih lanjut akibat dari kegiatan pemesanan makanan itu saat ada ingkar janji dari pihak konsumennya. Perdagangan yang berbasis teknologi canggih, e-commerce telah mereformasi perdagangan konvensional di mana interaksi antara konsumen dan perusahaan yang sebelumnya dilakukan secara langsung menjadi interaksi yang tidak langsung. E-commerce telah merubah paradigma bisnis klasik dengan menumbuhkan model-model interaksi antara produsen dan konsumen di dunia virtual. Sistem perdagangan yang dipakai dalam e-commerce dirancang untuk menkonsumentangani secara elektronik. Penkonsumentanganan elektronik ini dirancang mulai dari saat pembelian, pemeriksaan dan pengiriman (Abdul Halim Barkatullah dan Teguh Prasetyo. 2005, h. 7).

\section{Regulasi Mandiri Perusahaan Penyedia Layanan Aplikasi Transportasi Online Atas Konsumen Yang Ingkar Janji Dalam Pemesananmakananyang Didahulukan Oleh Driver}

Bicara mengenai pertanggungjawaban, ada jawaban yang cukup menyentuh dari driver, ia memilih tidak melapor kemanapun, hanya berlapangdada dan menyantap makanan hasil orderan fiktif itu bersama keluarganya. Disisi lain, adapula yang melaporkannya ke penyedia layanan aplikasi transportasi online. Karena dalam perjanjian kerja bersama kerugian yang dialami oleh driverakan ditanggung oleh pihak kantor penyedia layanan aplikasi transportasi online. Dan penyedia layanan aplikasi transportasi online hanya bisa mensubsidi Rp. 1.000.000 atas kerugian yang dialami oleh driver.

Syarat dan ketentuan perusahaan penyedia layanan aplikasi transportasi online, dapat dilihat regulasi mandiri dari perusahaan go-jek (Gojek, dalam www.go-jek.com) adalah sebagai berikut:

1) Jaminan 
Jurnal Ilmu Hukum

FAKULTAS HUKUM UMSU
Regulasi Mandiri Trnsportasi...(Erwin Asmadi)

Volume 4 Nomor 1, Januari-Juni 2019, 103-118 DOI: https://doi.org/10.30596/dll.v4i1.3164

Pihak go-jek tidak memberikan pernyataan, jaminan atau garansi untuk dapat dikonsumenlkannya, ketepatan waktu, kualitas, kesesuaian, ketersediaan, akurasi atau kelengkapan dari Layanan, Situs web dan/atau perangkat lunak Aplikasi, termasuk namun tidak terbatas pada Layanan yang diperoleh atau berasal dari Penyedia Layanan melalui penggunaan Aplikasi tersebut.

Pihak go-jek tidak menyatakan atau menjamin bahwa (a) penggunaan Layanan dan/atau Aplikasi akan aman, tepat waktu, tanpa gangguan atau terbebas dari kesalahan atau beroperasi dengan kombinasi dengan perangkat keras lain, perangkat lunak, sistem atau data, (b) Layanan akan memenuhi kebutuhan atau harapan konsumen, (c) setiap data yang tersimpan akan akurat atau dapat dikonsumenlkan, (d) kualitas produk, layanan, informasi, atau bahanbahan lain yang dibeli atau diperoleh oleh konsumen melalui Aplikasi akan memenuhi kebutuhan atau harapan konsumen, (e) kesalahan atau kecacatan dalam Aplikasi akan diperbaiki, atau (f) aplikasi atau server(-server)) yang menyediakan Aplikasi terbebas dari virus atau komponen berbahaya lainnya, atau (g) Aplikasi melacak konsumen atau kendaraan yang digunakan oleh Penyedia Layanan. Layanan disediakan untuk konsumen terbatas hanya pada dasar "sebagaimana adanya". Semua kondisi, pernyataan dan jaminan, baik tersurat, tersirat, yang diwajibkan oleh undang-undang atau sebaliknya, termasuk, namun tidak terbatas pada, jaminan yang tersirat mengenai jual beli, kesesuaian untuk tujuan tertentu, atau tidak adanya pelanggaran hak pihak ketiga, dengan ini dikecualikan dan dikesampingkan dengan batas tertinggi dan maksimum. Konsumen mengakui dan menyetujui bahwa seluruh risiko yang timbul dari penggunaan Layanan oleh konsumen tetap semata-mata dan sepenuhnya ada pada konsumen dan konsumen tidak akan memiliki hak untuk meminta ganti rugi apapun dari perusahaan.

\section{2) Tanggung jawab Go-jek}

Pihak go-jek tidak bertanggung jawab atas setiap cidera, kematian, kerusakan atau kerugian yang disebabkan oleh perilaku dari para Penyedia Layanan. Pihak go-jek juga tidak bertanggung jawab atas kesalahan, termasuk pelanggaran lalu lintas, atau tindakan kriminal yang dilakukan oleh Penyedia Layanan selama pelaksanaan Layanan. Penyedia Layanan hanya merupakan mitra kerja Pihak go-jek, bukan pegawai, agen atau perwakilan Pihak gojek.

Namun, Pihak go-jek peduli akan keselamatan pengguna Aplikasi dan, atas pertimbangan pribadi semata dan sepenuhnya, Pihak go-jek bersedia untuk memberikan bantuan keuangan jika pengguna mengalami kecelakaan, menderita cidera atau meninggal saat dijemput oleh Penyedia Layanan. Bantuan Pihak go-jek hanya berlaku sejak pengguna dijemput oleh Penyedia Layanan sampai pengguna mencapai tujuannya. Mohon mengingatkan Penyedia Layanan jika konsumen merasa tidak nyaman dengan cara Penyedia Layanan menyediakan layanan transportasi. Jumlah bantuan keuangan akan ditentukan berdasarkan kebijakan Pihak go-jek.

Pihak go-jek juga bersedia untuk memberikan bantuan keuangan sampai dengan Rp 
Jurnal Ilmu Hukum

FAKULTAS HUKUM UMSU
Regulasi Mandiri Trnsportasi...(Erwin Asmadi)

Volume 4 Nomor 1, Januari-Juni 2019, 103-118 DOI: https://doi.org/10.30596/dll.v4i1.3164

10.000.000 atas pertimbangan pribadi dan mutlak Pihak go-jek untuk barang yang hilang atau rusak saat menggunakan layanan dari Penyedia Layanan sepanjang barang tersebut mematuhi Ketentuan Penggunaan. Pihak go-jek tidak memiliki asuransi untuk barang yang dikirimkan dan oleh karena itu jika konsumen ingin barang tersebut diasuransikan selama pengiriman, silakan konsumen menghubungi penyedia asuransi konsumen.

Pihak go-jek menggunakan cara-cara teknis dan keamanan yang tepat dan wajar untuk menjaga Aplikasi aman dan terbebas dari virus dan kesalahan. Namun demikian, bagaimanapun efektifnya teknologi ini, tidak ada sistem keamanan yang tidak dapat ditembus. Oleh karena itu Pihak go-jek tidak dapat menjamin keamanan database Pihak go-jek dan Pihak go-jek juga tidak dapat menjamin bahwa informasi yang konsumen berikan tidak akan ditahan/terganggu saat sedang dikirimkan kepada Pihak go-jek.

Aplikasi ini dapat mengalami keterbatasan, penundaan, dan masalah-masalah lain yang terdapat dalam penggunaan internet dan komunikasi elektronik, termasuk perangkat yang digunakan oleh konsumen atau Penyedia Layanan rusak, tidak terhubung, berada di luar jangkauan, dimatikan atau tidak berfungsi. Pihak go-jek tidak bertanggung jawab atas keterlambatan, kegagalan pengiriman, kerusakan atau kerugian yang diakibatkan oleh masalah-masalah tersebut.

3) Pembatasan tanggung jawab

Setiap tuntutan terhadap perusahaan penyedia aplikasi transportasi dalam hal apapun oleh konsumen, akan dibatasi dengan jumlah total yang sebenarnya dibayar oleh dan/atau terhutang pada Konsumen ketika menggunakan Layanan selama peristiwa yang menimbulkan klaim tersebut. Dalam hal apapun perusahaan penyedia aplikasi transportasi dan/atau pemberi lisensi pihak perusahaan penyedia aplikasi transportasitidak akan bertanggung jawab kepada konsumen atau siapa pun atas biaya, bunga, kerusakan atau kerugian dalam segala jenis atau bentuk(termasuk cidera pribadi, gangguan emosi dan hilangnya data, barang, pendapatan, keuntungan, penggunaan atau keuntungan ekonomi lainnya). Perusahaan dan/atau pemberi lisensinya tidak akan bertanggung jawab atas kerugian, kerusakan atau cidera yang mungkin ditimbulkan oleh atau disebabkan oleh konsumen atau pada setiap orang untuk siapa konsumen telah memesan Layanan, termasuk namun tidak terbatas pada kerugian, kerusakan atau cidera yang timbul dari, atau dengan cara apapun sehubungan dengan Layanan dan/atau Aplikasi, termasuk namun tidak terbatas pada penggunaan atau ketidakmampuan untuk menggunakan Layanan dan/atau Aplikasi.

Konsumen secara tegas mengesampingkan dan melepaskan perusahaan penyedia aplikasi transportasi dari setiap dan semua kewajiban, tuntutan atau kerusakan yang timbul dari atau dengan cara apapun sehubungan dengan Penyedia Layanan. Perusahaan tidak akan menjadi pihak dalam sengketa, negosiasi sengketa antara konsumen dan Penyedia Layanan. Tanggung jawab untuk keputusan yang konsumen buat atas Layanan yang ditemukan melalui Aplikasi merupakan tanggung jawab dan melekat seutuhnya dengan dan pada konsumen. Konsumen secara tegas mengesampingkan dan melepaskan perusahaan penyedia aplikasi 
Jurnal Ilmu Hukum

FAKULTAS HUKUM UMSU
Regulasi Mandiri Trnsportasi...(Erwin Asmadi)

Volume 4 Nomor 1, Januari-Juni 2019, 103-118 DOI: https://doi.org/10.30596/dll.v4i1.3164

transportasi dari setiap dan semua kewajiban, tuntutan, penyebab tindakan, atau kerusakan yang timbul dari penggunaan Layanan, perangkat lunak dan/atau Aplikasi, atau dengan cara apapun terkait dengan Penyedia Layanan yang diperkenalkan kepada konsumen melalui Aplikasi.

Kualitas Layanan yang diperoleh melalui penggunaan Aplikasi ini sepenuhnya menjadi tanggung jawab Penyedia Layanan yang pada akhirnya memberikan Layanan untuk konsumen. Konsumen memahami, oleh karena itu, bahwa dengan menggunakan Aplikasi ini, Konsumen dapat dihadapkan pada transportasi yang berpotensi berbahaya, ofensif, berbahaya bagi anak di bawah umur, tidak aman atau tidak pantas, dan bahwa Konsumen menggunakan layanan atas risiko konsumen sendiri.

4) Ganti rugi

Penggunaan aplikasi dari perusahaan penyedia aplikasi transportasi, konsumen setuju bahwa konsumen akan membela, memberikan ganti rugi dan membebaskan Pihak go-jek, pemberi lisensi, afiliasi, dan masing-masing dari petugas, direktur, komisaris, karyawan, pengacara dan agen perusahaan penyedia aplikasi transportasi dari dan terhadap setiap dan semua klaim, biaya, kerusakan, kerugian, kewajiban dan biaya (termasuk biaya dan ongkos pengacara) yang timbul dari atau sehubungan dengan: (a) penggunaan Layanan dan/atau Aplikasi oleh konsumen, hubungan konsumen dengan Penyedia Layanan, penyedia pihak ketiga, mitra, pemasang iklan dan/atau sponsor, atau (b) pelanggaran atas atau tidak dipatuhinya salah satu Ketentuan Penggunaan atau peraturan perundang-undangan yang berlaku, baik yang disebutkan di sini atau tidak atau (c) pelanggaran konsumen terhadap hakhak pihak ketiga, termasuk Penyedia Layanan pihak ketiga yang diatur melalui Aplikasi, atau (d) penggunaan atau penyalahgunaan Aplikasi. Kewajiban pembelaan dan pemberian ganti rugi ini akan tetap berlaku walaupun Ketentuan Penggunaan dan penggunaan Situs oleh konsumen telah berakhir.

Tanggung jawab Perusahaan Penyedia Aplikasi Transportasiyang ada dalam pelaksanaan jasa transportasi berbasis aplikasi bermacam-macam. Mulai dari tanggung jawab terhadap kualitas pelayanan, privasi pengguna jasa, pajak, asuransi, sampai dengan keamanan transportasi itu sendiri. Letak tanggung jawab ini kemudian menjadi penting bagi Pemerintah, agar atas jasa transportasi tersebut kemudian jelas, siapa saja yang bertanggungjawab atas pelaksanaannya.

Teknologi Aplikasi memang merupakan buah kreativitas para pelaku usaha yang melihat adanya peluang bisnis dalam wilayah abu-abu di antara "Pembeli" dan "Penjual" jasa. Wilayah itulah yang dikembangkan para pelaku usaha dengan memanfaatkannya untuk berbisnis 'hubungan', dengan menciptakan teknologi aplikasi yang digunakan untuk menghubungkan masyarakat dan pelaku usaha. Akses ke pasar secara mudah dan cepat menjadi nilai jual dari Teknologi Aplikasi. Tetapi, ada konsumen nakal yang berusaha mencari celah untuk memanfaatkan teknologi dengan menyebabkan kerugian pada driveruntuk membuat barang dagangannya laku. 
Jurnal Ilmu Hukum

FAKULTAS HUKUM UMSU
Regulasi Mandiri Trnsportasi...(Erwin Asmadi)

Volume 4 Nomor 1, Januari-Juni 2019, 103-118 DOI: https://doi.org/10.30596/dll.v4i1.3164

Tanggungjawab Pemerintah ialah sebagai regualator, menciptakan perlindungan hukum bagi pelaku usaha dan konsumen yang kemungkinan diantara keduanya aka nada yang melakukan ingkar janji. Perdagangan yang melalui Sistem Elektronik saat ini diatur dalam Pasal 67 Undang-Undang Nomor 7 Tahun 2014 tentang Perdagangan, mewajibkan Pelaku Usaha yang memperdagangkan Barang dan/atau Jasa dengan menggunakan sistem elektronik untuk menyediakan data dan/atau informasi secara lengkap dan benar.

Data dan informasi tersebut meliputi identitas dan legalitas Pelaku Usaha, persyaratan teknis Barang dan Jasa, harga dan cara pembayaran, serta cara penyerahan barang. Pelanggaran terhadap kewajiban tersebut dapat menimbulkan konsekuensi berupa pencabutan izin bagi Pelaku Usaha. Berdasarkan Pasal 66 Undang-Undang Nomor 7 Tahun 2014 tentang Perdagangan, maka ketentuan lebih lanjut mengenai perdagangan melalui sistem elektronik akan diatur dalam Peraturan Pemerintah. Namun, hingga saat ini Peraturan Pemerintah tersebut belum dikeluarkan.

Ingkar janjinya konsumen terhadap pelaku usaha dalam kegiatan pemesanan makanan yang pembayarannya didahulukan oleh driver yang tidak terlacak, menjadi tanggungjawab pihak perusahaan penyelenggara transportasi untuk mengganti kerugian driver, dengan disertai bon pembelian dan bukti pemesanan fiktif dari konsumen. Namun, ada sebagian yang tidak mau mengklaim kerugiannya ke perusahaan dan hanya berlapangdada menerima musibah ingkar janji atas ulah konsumen yang dialaminya.

Perusahaaan yang melindungi dan mengayomi driver, memiliki itikad baik sesuai dengan syarat dan ketentuan perusahaannya mensubsidi kerugian driver korban ingkar janji atas ulah konsumen, yang diberikan maksimal Rp. 1.000 .000 (satu juta rupiah) dan dengan bukti bon serta orderan fiktif maka pihak perusahaan yang membelinya.

Di dalam rangka pelaksanaan perjanjian peranan itikad baik (tegoeder trouw) sungguh mempunyai arti yang sangat penting sekali. Bahkan, menurut R. Subekti, itikad baik itu dikatakan sebagai suatu sendi yang terpenting dalam hukum perjanjian. Hal ini dapat dipahami karena itikad baik merupakan hal yang utama untuk dapat melaksanakan suatu perjanjian dengan sebaik-baiknya dan sebagaimana mestinya (Riduan Syahrani. 2004, h. 247).

\section{KESIMPULAN DAN SARAN}

\section{Kesimpulan}

Berdasarkan uraian di atas, makaregulasi e-commerce dalam hukum positif Indonesia diatur melalui Undang-undang Nomor11 Tahun 2008 tentang Informasi dan Transaksi Elektronik sebagaimana yang telah diubah dengan Undang-undang Nomor19 Tahun 2016, Undang-undang Nomor 12 Tahun 2002 tentang Hak Cipta, Undang-undang Nomor 14 Tahun 2001 tentang Paten, Undang-undang Nomor 15 Tahun 2001 tentang Merek, Undang-undang Nomor 36 Tahun 1999 tentang Telekomunikasi, Undang-Undang Nomor 7 Tahun 2014 tentang Perdagangan, Undang-undang Nomor 8 Tahun 1999 tentang Perlindungan Konsumen, KUH Perdata dan lain-lain. 
Regulasi Mandiri Pemesanan Makanan melalui Layanan Aplikasi Transportasi Online merupakan ketentuan atau norma yang dibuat secara mandiri oleh penyelenggara sistem elektronik dalam menyelenggarakan sistem elektroniknya. Ketentuannya dapat dilihat di masing-masing website perusahaan layanan aplikasi transportasi online. Regulasi tersebut memuat pengertian umum, syarat, mekanisme, pertanggungjawaban dan lain-lain.

Konsumen yang ingkar janji dalam pemesanan makanan yang didahulukan oleh drivermelalui layanan aplikasi transportasi onlinetetap tunduk pada regulasi mandiri perusahaan penyedia. Secara hukum kesepakatan antara penyedia aplikasi layanan online dengan konsumen menentukan jaminan, tanggung jawab penyedia layanan, pembatasan tanggung jawab dan ganti rugi. Walaupun dalam regulasi mandiri tidak diatur sedemikian rupa pengembalian uang driver, namun dalam praktiknya driver diperkenankan mengklaim kerugian kepada penyedia aplikasi transportasi online dengan syarat menunjukkan bon tanda pembelian makanan.

\section{Saran}

Regulasi mandiri memuat aturan yang dibuat secara mandiri oleh perusahaan penyedia layanan aplikasi transportasi online. Uraiannya yang banyak dan detail, sepertinya kurang terbaca dan kurang dipahami secara baik, tidak hanya oleh konsumen (pengguna layanan aplikasi) tetapi oleh pihak terafiliasi (termasuk driver). Oleh karena itu perlu diatur bahwa regulasi tersebut dapat dibaca secara singkat. 
Jurnal Ilmu Hukum

FAKULTAS HUKUM UMSU
Regulasi Mandiri Trnsportasi...(Erwin Asmadi)

Volume 4 Nomor 1, Januari-Juni 2019, 103-118 DOI: https://doi.org/10.30596/dll.v4i1.3164

\section{DAFTAR PUSTAKA}

Asmadi, Erwin. (2018). Aspek Perlindungan Hukum Bagi Konsumen Dalam Penggunaan Aplikasi Pembayaran Elektronik (Electronic Payment). Jurnal Doktrina Journal of LawUniversitas Medan Area. Volume 1. Nomor 2, 97.

Barkatullah, Abdul Halim. (2010). Hak-hak Konsumen. Bandung: Nusa Media.

Barkatullah, Abdul Halim., \& Prasetyo, Teguh. (2005). Bisnis E-Commerce: Studi Sistem Keamanan dan Hukum di Indonesia. Yogyakarta: Pustaka Pelajar.

Makarim, Edmon. (2003). Kompilasi Hukum Telematika. Jakarta: PT. Raja Grafindo Persada

Pengertian Syarat dan Ketentuan Go-Jek Online (2017). Diakses pada tanggal 13 Oktober 2017 melalui www.go-jek.com.

Prastya, Defry. (2017) Aspek Hukum dalam Bisnis Online. Diakses pada tanggal 16 Oktober 2017 melalui www.defryprastya.blogsot.co.id, Diakses Tanggal 16 Oktober 2017.

Satria, Ridho. (2017). Ruang Lingkup E-Commerce. Diakses pada tanggal 18 Oktober 2017 melalui www.rsatriasucces.wordpress.com.

Soeroso, R. (1996). Pengantar Ilmu Hukum. Jakarta: Sinar Grafika.

Subekti, R. (2004). Kitab Undang-Undang Hukum Perdata. Jakarta: PT. Pradnya Paramita.

Syahrani, Riduan. (2004). Seluk Beluk dan Asas-Asas Hukum Perdata, Bandung: Alumni.

Undang-Undang Nomor 12 Tahun 2002 tentang Hak Cipta.

Undang-Undang Nomor 14 Tahun 2001 tentang Paten.

Undang-Undang Nomor 15 Tahun 2001 tentang Merek.

Undang-Undang Nomor 36 Tahun 1999 tentang Telekomunikasi.

Undang-Undang Nomor 7 Tahun 2014 tentang Perdagangan.

Undang-Undang Nomor 8 Tahun 1981 tentang Hukum Acara Pidana.

Undang-Undang Nomor 8 Tahun 1999 tentang Perlindungan Konsumen.

Undang-Undang Nomor11 Tahun 2008 tentang Informasi dan Transaksi Elektronik.

Undang-Undang Nomor19 Tahun 2016 tentang Perubahan Undang-undang Nomor11 Tahun 2008 tentang Informasi dan Transaksi Elektronik.

Yahman. (2015). Karaktersitik Ingkar janji Dan Tindak Pidana Penipuan. Jakarta: Prenada Media Group.

Zulham. (2013). Hukum Perlindungan Konsumen. Jakarta: Kencana Prenada Group. 